\title{
Analysis of the performance measurement models according to the requirements of the procurement business process
}

\author{
Nikola Komatina \\ University of Kragujevac, Faculty of Engineering, Sestre Janjić 6, Kragujevac, Serbia \\ nkomatina@kg.ac.rs \\ Snežana Nestić \\ University of Kragujevac, Faculty of Engineering, Sestre Janjić 6, Kragujevac, Serbia \\ s.nestic@kg.ac.rs \\ Aleksandar Aleksić \\ University of Kragujevac, Faculty of Engineering, Sestre Janjić 6, Kragujevac, Serbia \\ aaleksic@kg.ac.rs
}

Received (04-SEP-2018); Revised (01-JUN-2019); Accepted (17-JUN-2019); Published online (2-JUL-2019)

\begin{abstract}
The customer needs shape business activities continuously so the need for improving effectiveness stands as mandatory for overall business success. This paper analyses existing models for measuring the business processes performance from the aspect of their applicability to the procurement process. The paper first explains the concepts of enterprise performance, business process performance, and key performance indicators. Subsequently, a literature review of the identification problem of procurement process performance and key performance indicators is given. The models discussed and explained in this paper are Balanced Scorecard, SCOR model, performance measurement matrix, $A B C$ model, and DOE/NV model. The model comparison was based on several relevant criteria.
\end{abstract}

Key words: performance, $\mathrm{KPI}$, procurement, analysis

\section{INTRODUCTION}

The enterprise's business success can be perceived from several different aspects, which can be economic, but also technological and social. Customers, as the main entity for which enterprises are forced to constantly evaluate and reassess their business, directly or indirectly has an influence to the creation of a certain level of quality of products and services of the company. Therefore, quality as an indicator of business success is directly related to customers as the most important stakeholders. As far as the enterprises themselves are concerned, the performance indicators of business, which have the greatest importance for them, i.e. those that have essential importance, are profits, market competitiveness, brand recognition, and credibility. Despite the fact that these indicators form the basis of successful business, one should not neglect the social aspect, which is primarily reflected in the satisfaction of employees, relations with stakeholders and relations with the general public and the community.

The starting basis for determining the enterprise business success is identifying, analysing and measuring the performances that have the greatest impact on their business. The performance of an enterprise can be viewed as a value, which is measured directly or indirectly using certain qualitative or quantitative indicators [1], which are denoted as Key Performance Indicators (KPIs). The main objective of performance measurement is to determine which aspect of an enterprise's business does not achieve the desired business objectives and to take action to improve it on the basis of the performed analysis. In addition to measuring the enterprises' business success using performance measurement, it is also possible to measure the success of the realization of business processes. In this way, it is possible to determine which process activities need to be improved in order to achieve the objectives of the process.

There is a large number of developed performance measurement models in the relevant literature, which has different advantages and disadvantages. The same performance measurement system cannot be applied equally well in two different organizations, or in two different business processes. Many factors may influence the application of some model, such as the type of organization (productive or serviceable, profitable or not profitable, etc.), industry branch, enterprise size, etc. This also applies to business 
processes. A particular model does not have to be adequate to measure the performance of each business process within the same company, but it also does not have to be equally well-used to measure the performance of the same business process in different companies. One thing is certain, there is no best or universal model for measuring the performance of an enterprise or business process, so the choice of an optimal model depends on a number of characteristics, the purpose of the model, the complexity, the metrics, the organizational level to which it is applied, and so on.

Performance and key performance indicators are not the same for every business process. This is one of the reasons why we cannot establish universal metrics of business processes performance. In addition, the same performance does not have the same importance for each business process, and performance indicators do not have the same target value. Each enterprise, or enterprise management, defines and establishes the metric that best suits the company under consideration, as well as the model that best illustrates the performance of a business or the realization of business processes.

This paper considers the procurement business process, which has a significant impact on the operations of each company. Procurement plays an important role in the planning of financial resources and affects the overall profit of the company. In addition, the procurement process is directly related to the relationship with suppliers, and the quality of the raw materials that enter the production process depends on this process.

The models for the performance measurement analysed in this paper are Balanced Scorecard [2], SCOR model [3], performance measurement matrix [4], ABC model [5] and DOE/NV model [6]. These models are considered because they can be applied to the procurement business process. The subject of research is existing models for the measuring of the performance of enterprises and business processes, as well as their application to the business process of procurement. Part of the theoretical research refers to the identification of performance and their key indicators that correspond to the needs of success measuring of a particular process in any production company. The research analyzes existing models for performance measurement and compares them from the aspect of their applicability to the procurement process and other key characteristics. The problem to be solved by this research is the choice of the optimal model for the performance measurement of the procurement process, based on the analysis performed, as well as defining relevant performance and key performance indicators. Therefore, it is necessary to choose the measurement model that best meets the requirements of this business process.

The main goal of this paper is a literature review in the field of business process performance measurement, primarily procurement, comparative analysis of performance measurement models and the relevance of their application to the procurement business process.

The paper is organized as follows: In the second section procurement process performances and KPIs are explained, and ways for their identification. The performance measurement models are presented in section 3. Section 4 gives an analysis of considered performance measurement models and the selection of the optimal model for this purpose. The conclusion is given in the last, fifth section.

\section{PROCUREMENT PROCES PERFORMANCE AND KPIs}

The procurement process is a complex business process and can be decomposed into multiple subprocesses and activities. In different ways, authors define procurement subprocesses and therefore choose different performance and key performance indicators. Subprocesses whose performance measurements are defined according to the company's vision and goals, varying depending on the type of product or service, industry, ownership, economic situation, a request of stakeholders, etc.

Three different perspectives of measuring and managing the procurement performance process can be found in the literature. The first perspective speaks about approaches based on the observation of the procurement process as a whole, composed of several mutually-independent phases. The second perspective discusses the approaches that the procurement process regards as a complete and fully integrated process in the supply chain, while the third perspective refers to procurement as a comprehensive and independent process [7].

\subsection{Identification of the procurement process performance}

Generally, there are many examples and ways to define the performance of the procurement process and their key indicators. Saad et al. [8] classified the performance of the procurement process in two groups, as defined in the Procurement Performance Indicators Guide [9]: 1) effectiveness and 2) efficiency. In the effectiveness performance, the author places the integrity, productivity of the system, timeliness, quality, and price. In the efficiency of efficiency performance, the author lists the management, policies, and procedures of choosing suppliers, stakeholders, e-procurement and ease of procurement.

Chan and Qi [10] defined the Performance of Activity (POA) method used to identify and manage performance and KPIs, and this method can be applied to any business process. The POA method is based on decomposing business processes to activities and defining performance for each activity particularly. As the value of the process's performance, the aggregated 
value of all process activities is taken. Indicators of each activity are their effectiveness and efficiency. This model has a disadvantage, and that is the complexity of the model because identifying of all process activities and their key indicators are demanding process. In addition, the measurement process of the indicator requires a long time period. However, the method is very well structured, clearly and precisely defined.

Kakwezi and Nyeko [11] classify all the procurement process performance into two groups: 1) non-financial factors and 2) financial factors. Process data is collected through a survey of employees in the company, whose competence and importance are determined on the basis of criteria, such as the level of education, work experience in the company and the type of workplace. This model does not provide a precise way of measuring the considered indicators, which is a basic defect of the model. Also, the original model identifies the difference between financial and non-financial indicators in terms of their importance, which significantly contributes to the complexity of the model, but increases its reliability.

\section{PERFORMANCE MEASUREMENT MODELS}

Performance measurement is a prerequisite for successful performance management, and therefore for achieving the vision and strategic goals of the enterprise. An important requirement for making good business decisions is to establish an appropriate performance measurement system for each business process. Therefore, performance measurement cannot be viewed merely as a collection of data to be processed [12], nor as a set of unrelated tools, methods and techniques [13].

In general, there are a large number of established performance measurement models in the literature, which consider this problem from different perspectives. Some of the models put an accent on financial, some to non-financial performance, while some have focused on the stakeholder's demands, primarily costumes [14]. This paper analyses performance measurement models that are often used in literature, such as Balanced Scorecard, SCOR model, Performance measurement matrix, ABC model and DOE/NV. The paper does not analyse certain models that are also often encountered in the literature, and the reasons for which they were not taken into consideration when carrying out the analysis are explained in the next chapter.

\subsection{Balanced Scorecard}

The Balanced Scorecard Model (BSC) was developed by Kaplan and Norton in 1992 and further improved by $[2,15,16,17]$, in order to facilitate the application and improve the functionality of this model. Balanced Scorecard was created as a result of the study of the world's leading companies business, which was the first to recognize the shortcomings of traditional performance measurement models. Traditional models of performance measurement include models based exclusively on measuring financial indicators [18].

The BSC model can be applied at different levels of business [19]:

- at the company level - measurement of business performance to monitor the performance of the company as a system,

- the level of business unit of a company measuring business performance, by means of which the performance of a business unit is monitored within the system, and

- the level of a department - measuring business performance to monitor the performance of a department within business units.

The principle on which this model is based is that how customer satisfaction leads to financial success. Management using the BSC model monitors enterprise performance (process realization) through four perspectives [17]:

- objectives to be realized,

- performance indicators that will be used to measure the achievement of the goal,

- target values (targets): Target values for each of these indicators and

- initiatives (actions): which actions should be taken to achieve the goals.

In order to implement the BSC model in an enterprise, it is necessary to analyze first the existing state and environment (competition), to determine the vision and mission of the company, to define the strategy, to set out the perspectives, to identify the critical success factors and to define the indicators for each of the considered performances [20].

Defining the strategy defines the goals, as well as the resources needed to achieve the goals. Kaplan and Norton classify objectives are classified into four levels [2]: 1) financial level, 2) level of costumer, 3) level of process, and 4) level of learning and development.

Identification of Critical Success Factors allows an enterprise to achieve planned goals. The process of critical success factors identification is very complex and depends on many factors (types of industry, strategy, environment, etc.). Critical success factors can be designated as specific product characteristics that are most valued for the considered product type, and which enterprises from the same industrial branch characterized as the most important [21].

Defining the indicator (measure) is done by defining at least one measure for each performance of business processes, whether it is qualitative or quantitative. For each indicator, a description, measurement frequency, measuring tool and target values (targets) should be given.

Often, as the positive side of the BSC model, it is emphasized that this model a business process 
performance links with the goals of the organization [22], involves employees in process performance measurement, and allows management to easily determine which aspects of business do not function in accordance with goals [23]. The main objection to this model is that it is not a complete performance measurement system, but only a tool that management uses to monitor performance in relation to the set strategic goals [24]. In addition, the model does not express the interests of all stakeholders [25].

\subsection{SCOR}

One of the most commonly used performance measurement systems is the so-called SCOR model (Supply Chain Operations Reference), or a reference model of supply chain operations. It was established by the Supply Chain Council in order to provide an easier and more reliable assessment of the supply chain's efficiency. Since the model is based on measuring the performance of business processes, other than the supply chain, it can also be applied at the enterprise level. SCOR serves to identify unified processes of enterprises in order to meet customers' requirements.

Over time, this model has changed, with the aim of improving the new model in terms of efficiency and effectiveness compared to the previous version. This model does not describe some business processes, such as a sale process, a marketing process, a research process, or a product development process. It also includes, but does not treat special quality, information technology, and administration. SCOR model includes 6 key management processes that exist in each company within a supply chain [3]:
1) Plan,
2) Source,
3) Make,
4) Deliver,
5) Return and
6) Enable.

Performance analysis using the SCOR model is usually done when choosing a partner for cooperation, where potential cooperative companies can be evaluated on the basis of the considered indicators.

\subsection{Performance Measurement Matrix - PMM}

This model of performance measurement was developed by Keegan, Eiler, and Jones in 1989 [4], and due to its simplicity, it was one of the earliest accepted performance measurement models [26]. The model is based on a matrix that recognizes 4 types of performance: 1) financial, 2) non-financial, 3) internal, and 4) external. The appearance of the matrix for performance measurement is shown in Figure 1.
The performance measurement matrix is a flexible and simple model, which, although it does not display all performance attributes, can fit any performance measure. This matrix provides comprehensiveness because it integrates different types of business performance [18].

The basic disadvantage of the model is that it does not include users and human resources, and does not provide a clearly defined performance measurement process [27].

\subsection{Activity-Based Costing - ABC model}

ABC (Activity Based Costing) method is a measurement system that recognizes the cause-effect relationship between costs and activity of business processes. This model was developed in the eighties of the twentieth century by Harvard professors Kaplan and Cooper, and he presents the accounting answer to the process orientation [28].

The ABC method is based on the following assumptions [29]:

- in order to produce some product or provide some service, it is necessary to exist process activities,

- to perform process activities it is necessary to use different resources,

- activities are the basis for the allocation of costs and

- the causes of the use of resources and the causes of the activity are not necessarily related to the volume of production.

This method, in addition to determining more precise cost of business processes than traditional ones, by separately analyzing costs for each of the activities, also facilitates the decision-making process. Management uses this method to determine which process activities do not benefit or add value to the product, but also identify those activities that are not necessary at a given moment.

\subsection{DOE/NV}

The DOE/NV model of performance measurement is proposed by the U.S. Department of Energy Nevada Operations Office [6], by which this model get the name. The model was created as a result of studying the existing performance measurement models and can be used to measure performance at all levels of the organization.

The DOE/NV model consists of 11 steps [6]:

Step 1. Process Flow Identification: This is a very important step because any error can lead to unreliable or inadequate information. The output from this process is a list of all key processes and their flow diagrams.

Step 2. Identification of the critical activity being measured: critical activity is an activity that has a 
significant impact on the efficiency, effectiveness, quality, productivity, time and safety of the execution of a process. It is necessary to define one or more critical activities for each critical process and define the performance measures of the process. The outcome of this step is a list of critical activities.

Step 3. Determination of performance objectives: it is necessary for each of the performance measures to define the objectives that need to be achieved. The outcome of this step is a list of targets for each critical activity.

Step 4: Determining Performance Measures: In order to develop performance measures, it is necessary to carry out the following activities: 1) define the problem being considered, 2) identify the raw data to be translated into performance measures, 3 ) determine the location of the required data, 4) determines the approaches, i.e. the methods of measuring or estimating data, and 5) the frequency of measurements is determined. Outcomes from this step are performance measures with their characteristics.

Step 5. Identification of responsibilities: it is necessary to define responsible persons for collecting, processing and analysing data on achieved performance, to compare the achieved performance with the given objectives, and to undertake the necessary corrective actions. The output of this step is a list of people with their authority.

Step 6. Data collection: it is necessary to determine whether the data collected are relevant, whether there is sufficient data and whether the frequency of data collection is appropriate. The outcome of this step is an extended list of data.

Step 7. Performance Analysis: In this step, raw data is transformed into performance measures and is presented in a clear form, suitable for data analysis. The exit from this step is a performance report.

Step 8. Comparison of achieved performance with goals: achieved performance is compared with predefined goals, and depending on the performance deviation from the given goals, measures are proposed to improve the performance. Sometimes an additional review of the set goals is required, as the target performance value is incorrectly defined.

Step 9. Defining Corrective Action: If the performance achieved does not meet the set goals, it is necessary to define corrective actions to improve performance.

Step 10. Realization of corrective actions: in this step, the defined actions from the previous step are realized. This step is realized solely if corrective action is necessary. The exit from this step is a successful action plan.

Step 11. Re-evaluation of goals: it is necessary to regularly revise the goals because the opportunities and needs of the company in a modern business environment change very quickly. Sometimes some goals cannot be achieved due to lack of resources, so they need a change, and sometimes the change is needed when the company meets the set goals and wants to further improve its business. As a result of this step, it can be established that it is not necessary to change the current set goals.

The DOE/NV model of performance measurement can be applied at each level of the organization, or for each business process. However, the methodology within this model is completely undefined, and it does not provide any guidance on how to identify key processes and key activities, but also the way to determine performance measures that are monitored [18].

\section{ANALYSIS OF THE CONSIDERED MODELS AND SELECTION OF PROCUREMENT PROCESS PERFORMANCE MEASURING MODELS}

During the selection of the appropriate model for measuring the performance of an enterprise or business process, it is necessary to determine which model best suits the considered company/process from several aspects. When it comes to an enterprise, the selection of a model can depend on the size of an enterprise, type of industry, vision, goals, etc. When it comes to business processes, the most important thing is to find a model that best identifies the performance of the process and its KPIs and gives clear guidance on how the KPI measures are.

This paper considers the procurement process. The performance of this process is focused on cooperation with suppliers, price, time and flexibility. The considered models of performance measurement are evaluated according to how their measurement methodology corresponds to the procurement process and how much their characteristics are relevant to this process.

In the paper [18], tabular reviews of the comparative analysis of the model for performance measurement based on different criteria were shown, which served as a principle for comparing the model in this paper.

Tables 1 and 2 show models of performance measurement, analyzed on the basis of relevant criteria.

In Table 1, it can be seen that the models have, for the most part, different purposes. Some of them are used to identify problems, some to assess productivity, efficiency, effectiveness, or some other indicators, while others are used to make improvements. Each model has a baseline for determining performance measures. In addition, performance measures belong to different categories (costs, process measures, non-financial indicators, efficiency etc.). Also, three of the considered models have crisp and fuzzy boundaries performance measures type and just $A B C$ model has crisp performance measures type. 
Table 1. Analysis of the model of performance measurement according to the different criteria, adopted from [18]

\begin{tabular}{|c|c|c|c|c|}
\hline Model & Model purpose & $\begin{array}{l}\text { Basis for determining } \\
\text { performance measures }\end{array}$ & $\begin{array}{l}\text { Categories of } \\
\text { performance measures }\end{array}$ & $\begin{array}{l}\text { Performance measures } \\
\text { type: crisp vs. fuzzy } \\
\text { boundaries }\end{array}$ \\
\hline BSC & $\begin{array}{l}\text { Quick identification of } \\
\text { problematic parts of the } \\
\text { organization }\end{array}$ & Vision, goals and strategies & $\begin{array}{l}\text { Customer measures, } \\
\text { financial measures, } \\
\text { process measures and } \\
\text { learning and development } \\
\text { measures }\end{array}$ & crisp / fuzzy boundaries \\
\hline SCOR & $\begin{array}{l}\text { Description, measurement and } \\
\text { evaluation of supply chain }\end{array}$ & $\begin{array}{l}\text { Processes and subprocesses in } \\
\text { supply chain }\end{array}$ & $\begin{array}{l}\text { Strategic measures, } \\
\text { process measures for the } \\
\text { first three levels of the } \\
\text { model }\end{array}$ & crisp / fuzzy boundaries \\
\hline PMM & $\begin{array}{l}\text { Overview of performance } \\
\text { measures by category }\end{array}$ & l & $\begin{array}{l}\text { Financial and non-financial, } \\
\text { internal and external } \\
\text { measures }\end{array}$ & crisp / fuzzy boundaries \\
\hline ABC & Cost reduction & Process activities & Costs & crisp \\
\hline DOE/NV & $\begin{array}{l}\text { An assessment of enterprise } \\
\text { effectiveness }\end{array}$ & Process objectives & $\begin{array}{lr}\text { Processes } & \text { performance } \\
\text { measures } & \text { to assess } \\
\text { effectiveness } & \\
\end{array}$ & crisp / fuzzy boundaries \\
\hline
\end{tabular}

Table 2 shows the analysis of the performance measurement models according to four criteria. The specificity of the criteria relates to whether the model considered gives recommendations on how performance indicators are selected or the indicators are completely specified. The complexity of the model indicates whether the model is complex from one of three aspects: 1) in the data collection phase, 2) in the implementation, and 3) in exploitation. Regarding the criteria for stakeholders, it is better than the model includes a large number of stakeholders (internal and external), as they significantly affect the business of the company. As the last criterion, the model's flexibility shows how much the model is applicable in different organizations and at different levels of an organization.

Table 2. Analysis of the model of performance measurement according to the criteria: the specificity of the indicators to be measured, the complexity of the model, considered stakeholders, and model flexibility, adopted from [18]

\begin{tabular}{|c|c|c|c|c|}
\hline Model & $\begin{array}{l}\text { Specificity of the } \\
\text { indicators to be } \\
\text { measured }\end{array}$ & $\begin{array}{l}\text { The complexity of the } \\
\text { model }\end{array}$ & $\begin{array}{l}\text { Considered } \\
\text { stakeholders }\end{array}$ & Model flexibility \\
\hline BSC & There is no specification & $\begin{array}{l}\text { The model is partly } \\
\text { complex } \\
\text { (complex from one } \\
\text { aspect) }\end{array}$ & Customers & $\begin{array}{l}\text { The model is somewhat flexible, i.e. can be applied in } \\
\text { all organizations, but with significant / long-lasting } \\
\text { changes in the model }\end{array}$ \\
\hline SCOR & $\begin{array}{l}\text { Indicators are specified } \\
\text { (for each performance } \\
\text { attribute) }\end{array}$ & $\begin{array}{l}\text { The model is complex } \\
\text { (complex } \\
\text { is from two aspects) }\end{array}$ & $\begin{array}{l}\text { Customers and } \\
\text { suppliers }\end{array}$ & $\begin{array}{l}\text { The model is not flexible, that is, it is only defined for } \\
\text { a certain type of organization }\end{array}$ \\
\hline PMM & $\begin{array}{l}\text { Not specified, it is given } \\
\text { how to specify them }\end{array}$ & $\begin{array}{l}\text { The model is partly } \\
\text { complex } \\
\text { (complex from one } \\
\text { aspect) }\end{array}$ & $\begin{array}{l}\text { Stakeholders are not } \\
\text { considered }\end{array}$ & $\begin{array}{l}\text { The model is somewhat flexible, i.e. can be applied in } \\
\text { all organizations, but with significant / long-lasting } \\
\text { changes in the model }\end{array}$ \\
\hline$A B C$ & There is no specification & $\begin{array}{l}\text { The model is extremely } \\
\text { complex } \\
\text { (it is complex with all } \\
\text { three aspects) }\end{array}$ & $\begin{array}{l}\text { Stakeholders are not } \\
\text { considered }\end{array}$ & $\begin{array}{l}\text { The model is flexible and can be applied to wide and } \\
\text { diverse range of companies, but only on level of } \\
\text { different processes in the organization, not at the } \\
\text { level entire organization }\end{array}$ \\
\hline DOE/NV & $\begin{array}{l}\text { Not specified, it is given } \\
\text { how to specify them }\end{array}$ & $\begin{array}{l}\text { The model is extremely } \\
\text { complex } \\
\text { (it is complex with all } \\
\text { three aspects) }\end{array}$ & $\begin{array}{l}\text { Direct process } \\
\text { customers (users) }\end{array}$ & $\begin{array}{l}\text { The model is somewhat flexible, i.e. can be applied in } \\
\text { all organizations, but with significant / long-lasting } \\
\text { changes in the model }\end{array}$ \\
\hline
\end{tabular}

Table 3 shows the analysis of the criteria in the previous two tables, depending on whether they are appropriate for the procurement process. If the description of the criterion considered corresponds to 
the procurement process, it is marked with "+", otherwise "-", and if it is only relevant in a segment, but not completely, then such a phenomenon is indicated by "•".

Table 3. Analysis of the performance measurement models according to the requirements of the procurement process

\begin{tabular}{|l|c|c|c|c|c|c|c|}
\hline Model & $\begin{array}{l}\text { Model } \\
\text { purpose }\end{array}$ & $\begin{array}{l}\text { Basis for } \\
\text { determining } \\
\text { performance } \\
\text { measures }\end{array}$ & $\begin{array}{l}\text { Categories } \\
\text { of } \\
\text { performance } \\
\text { measures }\end{array}$ & $\begin{array}{l}\text { Specificity of the } \\
\text { indicators to be } \\
\text { measured }\end{array}$ & $\begin{array}{c}\text { The complexity } \\
\text { of the model }\end{array}$ & $\begin{array}{c}\text { Considered } \\
\text { stakeholders }\end{array}$ & $\begin{array}{c}\text { Model } \\
\text { flexibility }\end{array}$ \\
\hline BSC & + & + & + & $\bullet$ & $\bullet$ & - \\
\hline SCOR & $\bullet$ & + & + & $\bullet$ & - & - \\
\hline PMM & + & - & + & $\bullet$ & - & $\bullet$ \\
\hline ABC & + & + & $\bullet$ & $\bullet$ & - & $\bullet$ \\
\hline DOE/NV & + & + & + & $\bullet$ & - & + \\
\hline
\end{tabular}

The BSC model can be used to measure the performance of the procurement process, and in addition, it is a simple process of defining performance measures. This process encompasses a wide range of performance measure categories, which is certainly a positive factor. The other four criteria only partially meet the requirements of measuring the procurement process, but it is an important thing that is not too large a lack of this model.

The SCOR model has its application exclusively for supply chains, but since procurement is one of the processes for which this model has been developed, it can be said that the purpose of the model is neither positive nor negative. The biggest problem of this model is its complexity.

The PMM is a model that is negative in two aspects. This model does not define the basis for determining performance measures, and this model does not take into account the stakeholders. Given that the procurement process is directly related to suppliers, and customer satisfaction depends on it indirectly, this factor is very negative.

The $A B C$ model has a disadvantage reflected in the complexity of the model. The model is complex with all three aspects (data collection phase, implementation, and exploitation). Other criteria are good or satisfactory.

The DOE/NV model for performance measurement has the same disadvantage as the $A B C$ model, i.e. is complex with all three aspects. Also, the model requires frequent changes over time, but can, therefore, be applied in all types of organization.

It is important to note that all models considered in the paper [18] are not considered in this paper because they are completely inapplicable or inadequate for the procurement process according to one of these three criteria. For example, within the Tableau de Bord, stakeholders are not considered and there is a hierarchical connection, i.e. the model is applicable better at the level of the entire organization, not at the level of a single process. The DEA model specifies indicators that relate exclusively to efficiency and the model is very complex. The Pyramid Performance model is applicable at the level of the entire organization, less at the level of one process, and the model is not flexible enough. On the other hand, the Model Results-determinants does not take into account the requirements of the stakeholders, there is a hierarchical relationship between levels and performance measures are not specified. The EFQM (European Foundation for Quality Management) model is a highly complex model and is better applied to measure performance at the organization level, as well as comparing it with a competition.

\section{CONCLUSION}

In this paper models for measuring the performance of enterprises and processes are considered from the perspective of application to the business procurement business process. Considered models are Balanced Scorecard, SCOR model, Performance measurement matrix, $A B C$ model and DOE/NV model.

A model that has proven most suitable for measuring the performance of the procurement process is the Balanced Scorecard. One of the advantages of this model is that it connects the performance of business processes to the goals of the organization, that is, in this case, with the goals of the process. Also, employees are involved in the performance measurement process. The model can be applied to any business process, and there are author's claims that the BSC can be applied equally well in either small and mid-sized enterprises, or how Gumbus and Lussier said, in companies from 5 to 5,000 employees [30].

The basic disadvantage of the Balanced Scorecard model is that this model is not a complete performance measurement system, i.e. the KPIs, as well as the method of measurement, are not completely defined in 
the model. When the model is applied to the whole enterprise, the deficiency can be emphasized because the model does not take into account the interests of all stakeholders.

The model can be modified and improved in different ways. First of all, it is possible to define new performance measures, which apply to different stakeholders (eg suppliers). It is possible to integrate the model with some of the existing models, but also by creating reliable metrics for each business process. Depending on the company's strategy and business goals, the model can be modified and adapted to existing conditions.

The future directions of research relate to the extension of existing performance measurement models, with particular reference to the Balanced Scorecard model. The model can be integrated with one of the multicriteria decision-making methods $[31,32,33]$ when obtaining the KPI values determined by the assessment of experts or stakeholders. Since the human way of thinking is closer when the estimate is expressed by linguistic expressions, instead of precise numbers, the fuzzy sets theory can be applied to the improvement of the model $[8,34,35]$. As the last step in creating an optimal model for measuring the performance of an enterprise or business process, it is possible to develop software based on the considered model.

\section{REFERENCES}

[1] Enos, D. D. (2007). Performance improvement: Making it happen. Auerbach Publications.

[2] Kaplan, R. S., \& Norton, D. P. (1996). The balanced scorecard: Translating strategy into action, the president and fellows of Harvard College. Harvard Business Review, 75-85.

[3] Supply Chain Operations Reference (SCOR $\AA$ ) model: Version 11 (revision), Supply Chain Council Overview, http://docs. huihoo.com/scm/supply-chain-operations-referencemodel-r11.0.pdf, 27. 1. 2019.

[4] Keegan, D. P., Eiler, R. G., \& Jones, C. R. (1989). Are your performance measures obsolete?. Strategic Finance, 70(12), 45.

[5] Cooper, R., \& Kaplan, R. S. (1991). Profit priorities from activitybased costing. Harvard business review, 69(3), 130-135.

[6] Bellman, R., Droemer, D., Lohmann, M., \& Miller, C. (1994). Performance measurement process, guidance document (No. DOE/NV-382). USDOE Nevada Operations Office, Las Vegas, NV (United States).

[7] Abolbashari, M. H., Chang, E., Hussain, O. K., \& Saberi, M. (2018). Smart buyer: a Bayesian network modelling approach for measuring and improving procurement performance in organisations. Knowledge-Based Systems, 142, 127-148.

[8] Saad, S., Kunhu, N., \& Mohamed, A. (2016). A fuzzy-AHP multicriteria decision making model for procurement process. International Journal of Logistics Systems and Management (IJLSM), 23(1), 1-24.

[9] USAID. (2013) Procurement Performance Indicators Guide: Using Procurement Performance Indicators to Strengthen the Procurement Process for Public Health Commodities. Report, Arlington, USAID (AID-OAA-TO- 10-00064)

[10] Chan, F. T., \& Qi, H. J. (2003). Feasibility of performance measurement system for supply chain: a process-based approach and measures. Integrated manufacturing systems, 14(3), 179-190.

[11] Kakwezi, P. \& Nyeko, S. (2010). Procurement Processes and Performance: Efficient and Effectiveness of the Procurement Function. Retrieved April, 3, p.2011, pp.1-22.
[12] Golubovic, D., \& Radovic, M. (2010). Postupak merenja performansi procesa. Zbornik apstrakata i CD sa 12. Internacionalnog simpozijuma SYMORG 2010, Beograd: FON.

[13] Spasojević Brkić, V., Milanović, D., Knežević, S., Lazić, D., \& Milanović, T. (2012). Sistem menadžmenta kvalitetom i poslovne performanse.

[14] Lynch, R. L., \& Cross, K. F. (1995). Measure up!: Yardsticks for continuous improvement.

[15] Kaplan, R. S., \& Norton, D. P. (2001). The Strategy-Focused Organization. Boston: Harvard Business School Press.

[16] Kaplan, R. S., \& Norton, D. P. (2004). Strategy Maps: Converting Intangible Assets into Tangible Outcomes. Boston: Harvard Business School Press.

[17] Kaplan, R. S., \& Norton, D. P. (2006). Alignment: How to Apply the Balanced Scorecard to Corporate Strategy. Boston: Harvard Business School Press.

[18] Simeunović, B., Slović, D., \& Radaković, A. J. (2015). Analysis of process performance measurement models. Škola Biznisa, 2015(2), 49-64

[19] Stojanović Krstić N. (2014). Savremeni okviri merenja poslovnih performansi. Društvo ekonomista „Ekonomika”, 60(2), str. 169178

[20] Simeunović, B. P. (2015). Razvoj modela za merenje performansi procesa (Doctoral dissertation, Univerzitet u Beogradu, Fakultet organizacionih nauka).

[21] Johnson, G., \& Scholes, K. (2002). Exploring Corporate Strategy. 6th ed. Harlow, UK: Financial Times Prentice Hall.

[22] Jeston, J., \& Nelis, J. (2006). Business process management Practical guidelines to successful implementations. Oxford: Butter- Heinemann, Elsevier Ltd., Jordan Hill.

[23] Budd, C. S. (2010). Traditional measures in finance and accounting, problems, literature review, and TOC measures. Theory of constraints handbook.

[24] Sinclair, D., \& Zairi, M. (1995). Effective process management through performance measurement: part I-applications of total quality-based performance measurement. Business Process Reengineering \& Management Journal, 1(1), 75-88.

[25] Parisi, C. (2010). Using qualitative system dynamics to enhance the performance measurement of sustainability. In Business performance measurement and management (pp. 115-130). Springer, Berlin, Heidelberg.

[26] Neely, A., Kennerley, M., \& Adams, C. (2007). Performance measurement frameworks: a review (pp. 143-162). Cambridge University Press, Cambridge.

[27] Striteska, M., \& Spickova, M. (2012). Review and comparison of performance measurement systems. Journal of Organizational Management Studies, 2012, 1.

[28] Bosilj-Vukšić, V., Hernaus, T., \& Kovačič, A. (2008). Upravljanje poslovnim procesima: organizacijski i informacijski pristup. Školska knjiga.

[29] Antić, L., \& Georgijevski, M. (2010). Obračun troškova po aktivnostima zasnovan na vremenu. Ekonomske teme, 48(4), 499-513.

[30] Franceschini, F., Galetto, M., \& Maisano, D. (2007). Management by measurement: Designing key indicators and performance measurement systems. Springer Science \& Business Media.

[31] Asgari, N., \& Darestani, S. A. (2017). Application of multi-criteria decision making methods for balanced scorecard: a literature review investigation. International Journal of Services and Operations Management, 27(2), 262-283.

[32] Yien, J. M., Chen, K. H., Wu, C. W., \& Lee, T. L. (2017). Creating logistics assessment for logistics business by using a hybrid MCDM model. International Journal of Organizational Innovation (Online), 10(1), 83.

[33] Varmazyar, M., Dehghanbaghi, M., \& Afkhami, M. (2016). A novel hybrid MCDM model for performance evaluation of research and technology organizations based on BSC approach. Evaluation and program planning, 58, 125-140.

[34] Bhattacharya, A., Mohapatra, P., Kumar, V., Dey, P. K., Brady, M., Tiwari, M. K., \& Nudurupati, S. S. (2014). Green supply chain performance measurement using fuzzy ANP-based balanced scorecard: a collaborative decision-making approach. Production Planning \& Control, 25(8), 698-714.

[35] Özdemir, A., \& Tüysüz, F. (2017). An Integrated Fuzzy DEMATEL and Fuzzy ANP Based Balanced Scorecard Approach: Application in Turkish Higher Education Institutions. Journal of Multiple-Valued Logic \& Soft Computing, 28 